\title{
Distance Education and Online Dialogues: Between Themes and Identities
}

\author{
Aldo Sena de Oliveira, Anderson Luiz Machado \\ Universidade Federal de Santa Catarina, Blumenau, Brazil \\ Email: aldo.sena@ufsc.br
}

Received 30 May 2015; accepted 2 August 2015; published 5 August 2015

Copyright (C) 2015 by authors and Scientific Research Publishing Inc.

This work is licensed under the Creative Commons Attribution International License (CC BY). http://creativecommons.org/licenses/by/4.0/

(c) (i) Open Access

\section{Abstract}

This article presents questions relating to multiplicity of identities and subjectivities that postmodernity allows and its relations with the context of educational practices. The society has experienced in recent decades a great dynamization in information content with multiple possibilities for access to more diverse channels, allowing for new forms of organization and structuring of education and pedagogical practices. We believe that this postmodern context is characterized by a complex level of information and interaction between people. The technologies allow for the support of interactional learning in distance education (DE), by using virtual environments containing discussion forums, webchats, videos and online libraries among others. In this context, the type of thinking developed from classroom teaching and DE reveals the quality of the pedagogical practices used. One important issue to highlight in the article is: it can be said that there is a certain incompatibility, in general, when we observe the pedagogical practices used and thought of for the classroom when transposed to DE without concern for the specifics of each type of education. Once the challenges are known, it is possible to develop some strategies that can be used in distance education. We believe that it is possible to create an ampler curriculum, where the desired outcomes can be constructed, where many singularities will emerge, where affection and joy may be constant and self-referencing subjectivity may also be produced. Within this context, the question remains in the concern to create a learning environment where the social actors are effective participants in the building of true learning communities. It is necessary to be open and not fearful of diversity, to pursue problems and solutions, to capture the possible and impossible. These are not guarantees, but possibilities to develop practices that may maximize different forms of learning and minimize the inconsistencies observed in today's distance education model.

\section{Keywords}

Distance Education, Identities, Subjectivities, Incompatibilities, Postmodernity 


\section{Introduction}

In recent years, contemporary society experienced a great dynamization in information content with multiple possibilities for access to more diverse channels, allowing for new forms of organization and structuring of education and pedagogical practices. This increase in the possibilities for access to more diverse means of communication, to a certain extent, demonstrates greater democratization in providing themes, in a society built by interconnected subjects. This postmodern context is characterized by a complex level of information and interaction between people. We live today in a globalized society which experiences postmodern complexity under the aegis of streamlined relations by "cyberculture."

The sharing of information online, collaborative production and the socialization of knowledge differentiate themselves from other media models, such as radio and television, where viewers are still passive recipients. These technologies allow for the support of interactional learning in distance education (DE), by using virtual environments containing discussion forums, webchats, videos and online libraries among others (Oliveira, Branco, Brito, \& Souza, 2014).

Various authors (Wallace, 2002) have demonstrated the use of information communication technologies (ICT) as a possibility for a new teaching-learning paradigm, enabling a resource educational innovation. Their increasing use in learning contexts effectively contributes to the incorporation of new methodologies (Pragnell, Roselli \& Rossano, 2006). For Xavier (2010) globalization has created what he already considers a new world order, characterized by what he calls technocracy, bringing economical, ideological and political changes. In this "new" reality, DE can be made problematic with respect to its potential in terms of its almost unrestricted access to various fields of knowledge. It is possible to think of multidisciplinary environments which seek to consolidate learning, with the teacher-student interactive component only being reduced when considering the formal physical space of the classroom and academic universe. On the other hand, consider that virtual spaces can enable more individualized care and more detailed monitoring of the student by the teacher, through quantitative data recorded over the course of activities. It can be said, then, that there is an important interactive component that shortens the distances between the student and the teacher in this case. So a student may feel further removed from a teacher in a traditional classroom setting when compared with a teacher that allows for more interaction even if it is linked to a non-classroom setting. This paradox is one of the starting points to discuss issues involving distance education and to analyze and discuss psychopedagogical strategies that have permeated the education practice in university courses that are offered at distance.

The increase in undergraduate courses offered in Brazil, following the curriculum guidelines and regulatory requirements for the democratization of university education, accompanied the development of new ICTs. Although the conventional format for DE has been around for a long time, the advent of new technological devices has given it the more dynamic and interactive nature it currently has today. There was an increasing (re)structuring of teaching that went on to develop complementary activities and use media resources to develop studying and teaching strategies. This led to a boost in virtual service strategies and forms of discussion of the theoretical aspects of their disciplines in forums, webchats, video lessons and video conferencing allocated to the Virtual Learning Environment (VLE) (Castro \& Alves, 2007). It is important to note that the mere existence of ICTs does not guarantee the integration of the content and curriculum and it is necessary that they are properly integrated in the learning process to support and complement the practices developed in class. The integration among media resources, information technology and daily curriculum denotes the need for fundamental changes in the academic space and advocates for the development of education activities (Castro \& Alves, 2007).

For DE, there is a need for the development of meaningful strategies and coordination between the specific content and information overload that exists in virtual environments which must be observed.

\section{Online Tools and Virtual Dialogues: Propositions Surrounding Teaching}

Initially, there is a need to identify the position of the authors as educators concerned with the education and psychological development of students through teaching practices intentionally designed for distance education. It is on the basis of this position that this work is understood and the argument developed. It is understood that the psychological development process is an important parameter in forming attitudes and the development of pedagogical proposals to be leveraged in the VLE.

In this sense, it can be said that two concepts, in Brazil, have theorized psychological development both in the classroom and distance settings: while one considers it a natural process the other understands it as socio-his- 
torical and cultural process (Facci, 2004). Not surprisingly, the two concepts maintain two essentially antagonistic teaching positions. Consider the emergence of such attitudes as not only located within the quality of these assumptions, but as also criticizing the development of principles assumed from these issues. This work seeks to rethink distance education considering its relevance to teaching from the standpoint that it has social justification.

The teaching practice requires continuous efforts to overcome the difficulties faced in DE, while viewing the education of the student according to the flexibility of curricula and the promotion of subject matter. From here the first question arises: what is the importance of practices designed to establish a learning community? According to Palloff \& Pratt (2002), "the learning community is the vehicle through which learning takes place," thus emphasizing the importance of a community learning together. In a practical and objective manner, but without reducing the solution to a model, how can one consider the different stages, differentiated historical subjects, distinct objectives and diverse potentials? How can activities be thought of for DE considering the diversity of topics to be worked on in an online educational context? These are just some of the challenges which the authors have faced in recent years and addressed as a research activity as discussed throughout this paper. The new ICTs streamlined educational activities in recent decades with the advent of new possibilities of access to information. The speed with which the changes occurred in the educational space should be investigated. Consider the following: how can one prepare didactic-pedagogical activities that address these numerous possibilities? How can one think of the new relationships that occur in these interactive spaces and what roles they occupy in education? Based on the interaction and dialogic movement between teachers/tutors and students, how can one see the progress and setbacks provided for educational proposals mediated by technology? What are the institutional tools available to teachers/tutors so that they can expand their ways of working in virtual teaching/ learning spaces?

The type of thinking developed from classroom teaching and DE reveals the quality of the pedagogical practices used. Scientific concepts are the basis that mediate man's actions with objects and phenomena. When there is thought, do not deal with the object itself, but operate mentally with its representation, which allows the mental elaboration of objects which are not present in space or time. The concepts are thus representations of reality labeled for specific signs-the words, proceed from an objective fact and constitute a culturally specific form of ordering and designating categories of experience (Oliveira, 1997). Ideally, the various contents which the student comes across in the VLE constitute various conceptual fields that enable new forms of meaning expanding the perception of content and allowing changes in the shape and content of human thought. One should seek to recognize in educational activities evidence of the development of the mind via performance of mental operations with respect to the learning of scientific concepts.

\section{Networks, Knowledge and Identities: A Subjective Construction of Incompatibilities}

Firstly, the intention of the authors is to expose and discuss one of the possibilities of thinking of the identities and virtual environments according to the post-structuralist framework, not in order to disqualify other approaches, but in thinking of the contribution of this framework and its consequences for society, education, school and curriculum and educational planning policies. The considerations that follow make use of dialogic features built from the analysis of virtual learning environments and the observation of teaching practices experimented in these places.

A simple definition of identity denotes multiple conceptions based on historical, psychological and social issues that can be discussed in the scope of education. These concepts are embedded in the concept of distance education itself. The bending of the word identity in the singular or plural expresses a theoretical-conceptual positioning, which has connotations promoted from a psychoanalytic notion of the subject, or a mental process of acquiring identity, as well as the anthropological concept of a set of distinctive characteristics of a group, or the recent culturalist tendency to conceive identity as a moving celebration.

In a certain manner, the concept of identity is relatively new and the fact that it occupies such a prominent place in contemporary cultural theory is related to radical transformations underway in the world and, in particular, to the ruptures, discontinuities, displacements and instabilities that settle in the overview of theories, concepts and said postmodern manifestations. Identity is one of the modern constructs that shatters hopelessly. This state of affairs has been diagnosed as "identity crisis", a condition in which individuals and groups would be displaced in both their place in the world and within themselves. From a unified, centered, balanced, coherent 
and stable conception of identity, one passes fragmentation, ephemerality, mobility, superficiality, buoyancy. We can be one and many, at the same time and at different times. Identity appears as though it is adrift in time and space, making it permanently catchable, dockable, but, paradoxically, at the same time as slippery as the expression employed by Hall (1998).

It can be said that there is a certain incompatibility, in general, when we observe the pedagogical practices used and thought of for the classroom when transposed to DE without concern for the specifics of each type of education. Aside from the individual differences of each student and each institution, and leaving aside the significant differences related to socioeconomic and even geopolitical backgrounds of each case, it would be very hard to deny such inconsistency. There would be a divergence of time: a collective misfit between schools and their students in contemporary society, which, increasingly, appears as a mark of this era and a problem of this generation. Although it is not an absolute novelty, this inadequacy has become more indisputable in recent years, just as it was creating an almost perfect fit between those bodies and subjectivities on the one hand, and, on the other hand, mobile communication and information devices such as cell phones and laptop computers with internet access (Sibilia, 2012).

Of course, this is not a random or enigmatic phenomenon: there are historical and even anthropological explanations for this growing inconsistency. Such justifications include a wide range of socio-cultural, economic and political factors that were triggered in recent decades and that, although they are not free from complexities and even contradictions, are easily identifiable to those who went through a few decades of the last century and are not adults at the beginning of this new millennium. But these trends are now crystallizing and their decantation today, with the help of mobile devices and other technologies of recent popularization, is one of the reasons why the gap between the two universes is now inevitable: on the one hand the school, on the other hand the contemporaneous modes of being. A difficult gap to avoid while pretending that nothing is happening. Proposed here is the following examination: what are these changes that are so profound that they have been affecting bodies and subjectivities in recent times, and that now offer a glimpse into the consummation of a metamorphosis (Sibilia, 2012)?

It can be said that the new generations have in their genesis a transition component which affects the ways of being in the world, which contribute to the incompatibilities between contemporary educational experiences and the curricular elaborations of prior periods, as a critical basis which permeates the practices in classroom and distance teaching. The new subjectivities flourish and express their blatant incompatibility with such tools as they interlock with other artifacts.

If on one hand electronic devices affect our practices in contemporary society and our subjectivities, these can only be brought over from a necessity provoked in the popular imagination that felt the existence of such devices to be a necessity. The question, then, is the following: do these devices actually change us, or have they come to be from our previous modifications that harboured within us the desire for their existence?

While children, adolescents and young people go on to make continuous electronic devices, one observes an almost visceral relationship of interdependence, but which is not exclusive of theses generations. In a certain and contradictory manner the obsolete and old gears of centuries old institutions are oiled and continue operation with the traditional model of education which makes use of chalk and blackboards, regulations, bulletins, fixed schedules, room mapping of individual assessments written without consultation and oral lessons.

When we refer to education and, more specifically, DE, it is important that we make reflections that can at the very least respond to the question: what impacts do these artifacts and knowledge, hosted on virtual platforms, have on the subjectivities of those who use them daily?

Public policies aimed at DE enforce rules, define projects and homogeneous proposals, which often disregard the peculiarities of modality, the region, the culture, the people, while disregarding the heterogeneity, multiplicity and singularity. Deterritorialized education resists the established flows of official DE as it is rhizomatic and is not concerned with the establishment of "no false totality" (Gallo, 2008). It is not in the interest of deterritorialized education to impose solutions, what matters is to create connections, networks and singularity.

From the analysis of the crisis of disciplinary societies and the rapid implementation of a new way of life, Gilles Deleuze presents a strong statement, “these educational institutions are doomed” (Deleuze, 2002). The author understood that there is no possible amendment to these antiquated inventions because their life cycle is concluded and now the schools have lost their historical sense. "It is just to manage their agony and take people to the installation of the new forces that are announced," said Deleuze.

From these assumptions, and denounces from the acts of recognition experienced by DE, an analysis can be 
made from Deleuze's work, the foundation of a philosophy of difference and whose construction is of fundamental interest, from this theoretical construction, in which the teacher is in a constant state of becoming. Thus, it is possible and desirable to approach several other readings on the subject in question. In Nietzsche, for example, there is a close relationship between thinking, representation and difference when considering recognition and production of new values as meaningful beams within the subject that produces them.

\section{Conclusion}

Once the challenges are known, it is possible to develop some strategies that can be used in distance education. It is possible to create an ampler curriculum, where the desired outcomes can be constructed, where many singularities will emerge, where affection and joy may be constant and self-referencing subjectivity may also be produced.

The elaboration of a proposal for distance education without borders must have a focus on many voices, favoring the expression of the sensorial diversity, polyphony-simultaneously combining many voices in an attempt to increase the degree of open communication. The multiple intersection as the main methodology in virtual learning environments enables the interaction of various points of view. The communication in virtual environments used for the formation of online teachers, is in general, verticalized. The instances of power struggle in this environment do not, to an extent, favor dialogue. They do not inspire enthusiasm, imposing what must be learned, taught, discussed; favoring, to a certain extent, the action of the voyeur, the observer, of the one who does not produce anything, but consumes what is produced in the virtual reality. In terms of transversal communication, we are dealing with listening and experiencing the singularities, the differences, to the detriment of the common sense and/or consensus. The transversal communication can catalyze affections, promoting the development of enthusiasm and producing self-referencing subjectivity.

Technical resources are not solely sufficient to attend to all the peculiarities. Thus, tutors and monitors are necessary to listen to and to meet the needs of each person. Populating the cyberspace goes hand in hand with the quality and the freedom generated by the group. As previously mentioned, the development of this environment is initially guided by the concept of the teacher as designer of the educational space. The quality and intensity of the interaction, the nature of the reception, the stimulus and the appearance promoted by the space have often in the teacher, the image of a jump starter.

Once the use of technologies of information and communication (TIC) starts to expand more intensely in terms of the learning process, it is necessary for the various members (teachers, monitors, tutors, students) to express the differences, the interactions, the enthusiasm and the will. Within this context, the question remains in the concern to create a learning environment where the social actors are effective participants in the building of true learning communities. It is necessary to be open and not fearful of diversity, to pursue problems and solutions, to capture the possible and impossible. These are not guarantees, but possibilities to develop practices that may maximize different forms of learning and minimize the inconsistencies observed in today's distance education model.

\section{References}

Castro, M. F. A., \& Alves, L. A. (2007). The Implementation and Use of Computers in Education in Brazil: Niterói City/Rio de Janeiro. Computers \& Education, 49, 1378-1386. http://dx.doi.org/10.1016/j.compedu.2006.03.002

Deleuze, G. E. (2002). Practical Philosophy. São Paulo: Editora.

Facci, M. G. D. (2004). The Periodization of Individual Psychological Development from the Perspective of Leontiev, Elkonin and Vygotsky. Cadernos CEDES, Campinas, 24. http://dx.doi.org/10.1590/S0101-32622004000100005

Gallo, S. (2008). Deleuze and Education. Belo Horizonte: Autêntica.

Hall, S. (1998). Cultural Identities in Postmodernity (2 ed.). Translation of Tomaz T. da Silva e Guacira Louro. Rio de Janeiro: DP\&A Ed.

Oliveira, A. S., Branco, N. B. C., Brito, M. A., \& Souza, T. C. R. (2014). Reporting on Shared Teaching in Distance Education. Química Nova na Escola, 36, 37-43.

Oliveira, M. K. de (1997). On Individual Differences and Cultural Differences: The Place of the 10-Historical Approach. In J. G. Aquino (Ed.), Error and Failure in School: Theoretical and Practical Alternatives (pp. 45-61). São Paulo: Summus.

Palloff, R., \& Pratt, K. (2002). Building Learning Communities in Cyberspace. Porto Alegre: Artmed.

Pragnell, M. V., Roselli, T., \& Rossano, V. (2006). Can a Hypermedia Cooperative eLearning Environment Stimulate Con- 
structive Collaboration? Educational Technology \& Society, 9, 119-132.

Sibilia, P. (2012). Networks or Walls: The School in Dispersion Times (224 p). Translation of Vera Ribeiro. Rio de Janeiro: Contraponto.

Wallace, R. M. (2002). The Internet as a Site for Changing Practice: The Case of Ms. Owens. Research in Science Education, 32, 465-487. http://dx.doi.org/10.1023/A:1022477832695

Xavier, A. C. (2010). Reading, Text and Hypertext. In L. A. Marcuschi, \& A. C. Xavier (Eds.), Hypertext and Digital Genres: New Forms of Construction of Meaning (pp. 207-220). São Paulo: Cortez Editora. 